\title{
A Few Reflexions on God, Philosophy, Theology, and Faith
}

\author{
Davor Pećnjak* \\ davor@ifzg.hr \\ https://orcid.org/0000-0001-9506-053X
}

https://doi.org/10.31192/np.18.1.5

UDC/UDK: 141.4

27-184.3

Pregledni članak / Review

Primljeno/Received: 25. listopada 2019. / Oct 25, 2019

Prihvaćeno/Accepted: 17. siječnja 2020. / Jan 17, 2020

In trying to understand God and faith in a proper way, philosophy and theology could be very complementary. I would like to review and examine a few modern challenges and relationships between philosophy, theology and faith, seen also from important hints from history of these disciplines. I shall just take some points I consider as the most interesting. I would suggest that the most important relationship between philosophy and theology is threefold: pure philosophical works arguing for theistic conclusion; philosophical explications of existing theological matters, and there is philosophical theology - mixed philosophical and theological components densely intertwined in texts. I give some examples of problems of interest for both disciplines and what significance the solutions, in general, can have for practical faith.

Key words: Catholicism, faith, God, philosophy, theology.

\footnotetext{
* Davor Pećnjak, PhD, research fellow, Institute of Philosophy, Ul. grada Vukovara 54, HR-10000 Zagreb, Croatia.
} 


\section{Introduction}

God is the creator of the world and human beings and God revealed Himself through the texts collected in the Bible. Practical faith is most important to be in harmony with the God, other human beings, the world and oneself, and, most importantly, to enable each human being to be saved for eternal life in heaven. But, philosophy and theology also strive to assist in explaining the teachings of the Bible and of the Church.

In this article I would like to examine a few modern relationships, and perhaps, challenges, between philosophy, theology and faith. ${ }^{1}$ I shall not neglect some important hints from history of these areas. I do not pretend to be exhaustive, but I shall just take some points I consider as the most interesting.

\section{God and Theology}

\subsection{Belief in God}

Someone can believe that God exists; someone can believe that God does not exist. We cannot have rigorous knowledge, for example, that God exists as we can have certain knowledge that the table is now in front of us (neglect all the sceptical intrusions here, let's look from the viewpoint of common sense). But Catholic faith is based on God's revelation to man which is contained in the Bible. This is the most certain way for the belief in God. Perhaps the most important part, though all parts are important, is the New Testament, in which God, through the second Divine Person - the Son - Jesus Christ - that had been living among us, gave His words directly. So, on the basis of biblical texts, Catholic theology (as well as Christian theologies of other Christian denominations) is formed to explain it further. Though, for example, Gospels are very clear, they are also multilayered so they can be, at some points, not unambiguous. This is much more evident in the Old testament; texts of the Old Testament, of course, has to be explained, firstly, according to the time in which they are written - and this is achieved primarily by historical and stylistic analysis, but still then, there are many points that have to be explained both theologically and philosophically.

\footnotetext{
${ }_{1}$ This is an extended version of my text $» B o g$, filozofija, vjera, sloboda «, published in Croatian in Boris KOŽNJAK, (ur.), Godišnjak za filozofiju. Uloga i mjesto filozofije u suvremenom društvu, Zagreb, Institut za filozofiju, 2018, 137-142. Here, I expand on some previous ideas. I would like to thank Boris Kožnjak, as the editor of the aforementioned volume, for the permission to use from the material from that text.
} 


\subsection{Divine Words and Theology}

Theology is needed to explain multilayeredness and all the meanings of the Divine words, commandments, prescriptions, advices and so on. Theology analyses texts in complex ways, but the final test must be, again, the Bible and the official teaching, non-ambiguously derived and confirmed from the Bible. The Bible is at the same time a starting point and final point as well as a source and a test for Catholic theology. ${ }^{2}$

One method of theology, among many it uses, is certainly, a conceptual analysis in clarifying issues. This is something theology shares with philosophy. Principal aim of theology - to fully understand the words and deeds of God - is itself multilayered. I shall mention only two layers which are interesting for our discussion here. One layer of theology is its own profession as profession. The other layer is service it does for formulating official teachings, official opinions on many important personal, social and global matters and for composing official documents.

When I say that Gospels are very clear, I would like to say that anyone reading them or hearing about their meanings and contents (of course, correctly and truthfully conveyed) can easily grasp what they say. In the first place, we hear what and how we should live this transient life on Earth to earn eternal life in Heaven after resurrection. It is to be expected that they are clear, because God turns to each and everyone, to every single human being, because all human beings are His creations. All human beings are called to sainthood, all are »invited « to join God after this life in Earth. But, of course, firstly we must »join« Him here in our life on Earth.

As God intended different services for different people, different human beings have different mental (and physical) capacities, so Gospels should be clear enough to provide for anyone. And since God is omnipotent, He can make His original teaching in the form that anyone can understand it by himself or herself, at least at the basic important level. (Of course, severely mentally incapacitated people are such that we do not expect them to understand and we do not consider them as blameworthy for not understanding and, perhaps for not conducting themselves because they are incapacitated for this, so we owe them full respect, help and mercy). Good example how philosophy can provide a good support for such thoughts is text De quindecim problematibus (On Fifteen Problems) of Albert the Great ${ }^{3}$ - in question one he argues convincingly that soul of one human being is not numerically the same as the

\footnotetext{
${ }^{2}$ See for example Alfred FREDDOSO, Two Roles for Catholic Philosophers, in John P. O'CALLAGHAN and Thomas S. HIBBS (eds.), Recovering Nature: Essays in Natural Philosophy, Ethics, and Metaphysics in Honor of Ralph McInerny, Notre Dame, IN, University of Notre Dame Press, 1999, 229-252.

3 Albertus MAGNUS, De quindecim problematibus, ed. and trans. Tomo Vereš, Zagreb, Demetra, 1994, 78-133; this is Latin and Croatian text.
} 
soul of another human being; so, each human being has its own separate soul, and these numerically different souls also differ in their powers from the soul (God) from which they gained their own particular existences; further, mind, which is essential to soul, is also different in each separate singular human being. Though Albert the Great does not say it explicitly, here we may add that if the souls and minds are different numerically, then it is to expect that they will differ in their powers in comparison to each other, which is, in fact, also empirically obvious.

\subsection{Theology and the Help of Philosophy}

But there can be situations in the development of the world, which Catholics always should look like as time unfolding of the history of salvation, where it could initially be unclear how to apply God's commandments, rules, prescriptions, combined with already official teachings of the Catholic Church, to new situations which are or can be morally, socially and religiously significant. Theology must proceed here. And in these situations, philosophy surely can be of help for theology. Philosophy, as a rigorous conceptual analysis, can clarify overall issues around a problem. This clarification can be, then a starting point, although in a very advanced form, so not starting literally, for further theological explication and explanation of some problem, or doctrinal matter, or specific application on moral issues, for example, as well as on other matters. So, in a sense, philosophy can be ancilla theologiae in a very positive sense. This serving is twofold: first, methodological, theology can profit from rigorous conceptual analysis employed in philosophy; second, theology can employ specific results of philosophy - its arguments, theories or conclusions concerning certain issues which are of interest for theology and faith in general, or for some particular issue.

At this point, I would like just to add that Albert the Great recommended philosophy in general, as a tool that can be used in discussions with philosophers who are not friendly to Catholic or Christian teachings. ${ }^{4}$ Furthermore, his attitude towards philosophy is formed by already mentioned argument that human intellect - mind - as part of the soul, gained its form and existence from God, so it is endowed by the light from the Divine source, and so philosophy, as an intellectual activity, cannot be contradictory to theology.

\footnotetext{
${ }^{4}$ Frederick COPLESTON, A History of Philosophy, vol. 2, New York, Doubleday, 1993, 296.
} 


\section{Three Kinds of Relations Between Philosophy and Theology}

On the other hand, there are many problems which are concerned with God or faith which, though very interesting in themselves, are remotely connected with practical issues of Catholic faith or Christianity in general. Perhaps they even have nothing to do with important practical and doctrinal issues. But, because they are genuine conceptual problems connected with Catholic views, there is a fertile area, at least for professional philosophers and theologians, to meet here trying to solve this kind of problems.

If we would like to think about relationships between theology and philosophy regarding structure of texts, I think that we can find three kinds of significant relationships between philosophy and theology, i.e. philosophical and theological texts:

1. Pure philosophical work arguing for theistic conclusion

2. Philosophical explication of theological matters (which may or may not serve for formulating further, purely theological work, or can be useful for doctrinal formulations or even for official teaching)

3. Philosophical theology - mixed texts - philosophical and theological components densely intertwined

I would now like to illustrate more fundamental and more exotic kinds of problems and these three kinds of relationships between theology and philosophy.

\subsection{Philosophy and the Theistic Conclusion}

Very good example for the first kind mentioned above is John Foster's book Divine Lawmaker ${ }^{5}$. Here, Foster try to solve pure philosophical questions and problems, applying philosophical reasoning without invoking anything from revelation or teaching or theological nature, but finally argues for the theistic significant conclusion. Namely, Foster tries to show how we can solve the problem what laws of nature are, where do they come from; correlated with this problem is, of course, the problem of induction and regularities, especially those we find in nature. By carefully employing reason and philosophical analysis, he forcefully argues that the best way we can understand regularities in nature and why we can formulate laws of nature is to show that regularities are imposed in or on nature (universe) just as regularities by some personal agent, who has immense knowledge and power etc., i.e. which is God. So, we have an explanation of regularities, how we can inductively know about them and

\footnotetext{
${ }^{5}$ John FOSTER, The Divine Lawmaker, Oxford, Clarendon Press, 2004.
} 
what laws of nature are and that there is a God who created universe thus and is the cause of regularities as regularities - and so of laws of nature. Moreover, on purely philosophical grounds, Foster argues that being that is God should have attributes which are traditionally predicated of Him in Judeo-Christian tradition, so he equated his god with Judeo-Christian God. We have here a very convincing, purely philosophical arguments and explanations which are completely in accordance with Christian and Catholic teaching in Foster's book.

Clear examples are, of course, philosophical arguments that purport to show directly that there must be a divine being or that from physical and metaphysical structure of our universe and its beings, objects, and entities, it follows, or that at least, the best kind of explanation is the existence of the divine being, e.g. God, as a creator of all that. Just to present and review briefly a few kinds of purely philosophical arguments such as are ontological and cosmological arguments ${ }^{6}$. Ontological argument claims that from the concept of God alone, it follows that God exists. Namely, God is, by definition, a perfect being. In medieval times, the existence was considered as one of the perfections - what does not exist or is only possible, is not perfect at all or is less perfect than beings that actually exist - so if everyone agrees that God is a perfect being, moreover, that God is the supremely perfect being, then He exemplify all of the perfections - God must exist because existence is one of the perfections. Another variant says that God as a supreme being, which He is by definition, cannot not to exist. It is more perfect for a being to be such that there is even no possibility for it not to exist. So, God is a necessary being - but if necessary then God surely exists. Still another variant says that if it is merely possible that there be a necessary being, then that being exists. This is because if it is true that it is possible that necessarily God exists then necessarily, God exists must be true as well and so God (necessarily) exists. It seems that it is sufficient that we can provide that being as God as is conceptually conceived, is possible. There are several other variants of this argument as well as critiques of them.

Variants of cosmological argument try to establish that there is a necessary being from the existence of contingent beings and, further, that that being is God. Namely it seems that it is possible that the universe does not exist and,

\footnotetext{
${ }^{6}$ Originator of the ontological argument is St. Anselm of Canterbury in his Proslogion; see Anselm of CANTERBURY, The Major Works, edited by Brian Davies and Brian Leftow, Oxford, Oxford University Press, 1998, 82-122; For contemporary debate see Charles HARTSHORNE, The Logic of Perfection, Chicago and La Salle, Open Court, 1962/1991, 28-117, Graham OPPY, Ontological Arguments and Belief in God, Cambridge, Cambridge University Press, 1995, Richard GALE, On the Nature and Existence of God, Cambridge, Cambridge University Press, 199. For cosmological argument see for example St. Thomas AQUINAS, Summa Theologica, trans. by the Fathers of the English Dominican Province, Benziger, 1947, 13-16, Richard SWINBURNE, The Existence of God, Oxford, Clarendon Press, 1979, William ROWE, The Cosmological Argument, New York, Fordham University Press, 1975/1998; Timothy O'CONNOR, Theism and Ultimate Explanation, Chichester, Wiley-Blackwell, 2012, Charles TALIAFERRO, Contemporary Philosophy of Religion, Malden and Oxford, Blackwell, 353-364.
} 
as well that either item in it is such that it is also possible for it not to exist. So, our universe and entities in it are contingent. But we cannot have a full explanation of the existence of the universe and entities in it in such a way that each and every contingent entity is explained by another contingent entity. In such a way we can always ask, for any contingent entity and as well for a whole series of contingent entities (even if infinite) why they exist rather than not. So, cosmological arguments of this variance try to show that there must be a necessary entity which has the reason for its existence in itself and can explain the existence of contingent beings. Another variant purports to show that there could not be an infinite series of (contingent) causes and effects - because then there could not be a first cause - so this series must end somewhere and it follows that the first cause has to be different in kind than all other causes. But, even if there is an infinite series of causes and effects, there should be an explanation why this is so - why that infinite series of causes and effects obtains at all. Again, there should be an explanation which should invoke an entity of a different kind - so, not a contingent one - than are the mere causes and effects in the universe. The cause that sustains and so explains even this infinite series should be entity that is, of course, not one of the members in the series but outside it and has a necessary existence. Further considerations can be added here that show that that being is in fact God traditionally conceived. We see how such pure philosophical reflexion can support revealed faith.

\subsection{Philosophy Explicates Matters of Theological Importance}

An example of the question or problem which is not so significant, at least directly, for practical theology and practical faith, but which is very interesting theologically and philosophically, is, for example, the problem about God and the existence of abstract entities like propositions, properties and mathematical entities - numbers, functions, ideal geometrical bodies, and other such abstracta. This problem is also an example of the second kind mentioned above. Namely, God is the creator of everything and everything depends on Him in its existence, but on the other hand, mathematical entities or propositions are considered to be abstract entities which do not have existence in space and time, and many such entities are considered as necessary beings. But if they are necessary, then they have existence secured by themselves, by their very necessity. Namely, necessary being is such that it is not possible for it not to exist. So, it would seem that somehow they escape creating by God; and not only they escape creating, but, if necessary, then they are completely independent in their existence from God - and that solution is unacceptable because there would be entities that do not depend in any way on God. Small number of people, if a single person only, would be moved by this problem practically even if theists do not find an acceptable solution. Of course, not finding a suitable solution 
would be embarrassing, because it would provide, from human reason alone, that perhaps there are entities on which God somehow does not have a control or are independent from Him, or that can put in jeopardy His essential attribute of omnipotence. But, of course, there are solutions that are in accordance with the Christian and Catholic doctrines. For example, Plantinga argues ${ }^{7}$ that God affirms the existence of all propositions and, of course, affirms the truth only of true propositions, and since God exists in every possible world, those propositions which are true in every possible world we consider as necessary because it is essentially in God's nature to affirm the truth of those propositions in such a way. Menzel and Morris argue ${ }^{8}$ for so-called theistic activism - the main thesis is that necessary abstract entities are necessary only in the sense that they exist in all possible worlds; but we do not have an explanation why is it so. The question about their creation is still left open and so we may say that they are dependent on God and God makes them in every possible world.

One attractive solution for the theist may be a kind of denying platonism. Elaborate anti-platonism is offered by $\mathrm{Craig}^{9}$ in the following way. Ontogical commitment, in a nutshell, introduced by Quine ${ }^{10}$, says that we are committed to those objects which bound variables refer to, or are capable of referring, in sentences in a good theory. So, if there is a sentence »there exists number 3452 «, and since that this is a sentence in a good mathematical theory, we are committed to the existence of number 3452 (as well as other numbers from an elaborate arithmetical theory), platonists would argue (Quine would not be one of them). Craigg ${ }^{11}$ set out to argue that »one is free to quantify over whatever one wishes independent of the question of whether those things actually exist." Craig also accepts that the "purpose of the existential quantifier is simply to facilitate logical inferences (...) without making ontological commitments. «12 Embracing fictionalism which says that mathematicians making their axiomatic systems are free to devise (coherent) axiomatic systems as they wish (analogously to writers in literature and fiction) and to draw the consequences from basic axioms and postulates, Craig ${ }^{13}$, relying on Potter $^{14}$, says that taking »the axioms of competing theories as postulates whose consequences may be

\footnotetext{
7 Alvin PLANTINGA, Does God Have a Nature?, Milwaukee, Marquette University Press, 1980, 140-146.

8 Thomas MORRIS and Christopher MENZEL, Absolute Creation, American Philosophical Quarterly, 23 (1986) 353-362.

9 William Lane CRAIG, Anti-Platonism, in Paul GOULD (ed.), Beyond the Control of God? Six Views on the Problem of God and Abstract Objects, New York, Bloomsbury, 2014, 113-142.

${ }^{10}$ Willard van Orman QUINE, On what there is, in Willard van Orman QUINE, From a Logical Point of View, Cambridge, Mass., Harvard University Press, 1953,1-19; see also Alyssa NEY, Metaphysics, New York and London, Routledge, 2014, 37-48.

${ }^{11}$ Craig, Anti-Platonism, 119.

${ }^{12}$ Craig, ibid., 119.

${ }^{13}$ Craig, ibid., 118.

${ }^{14}$ Michael POTTER, Set Theory and its Philosophy, Oxford, Oxford University Press, 2004.
} 
explored, invites us, in effect, to make believe that axioms are true without committing ourselves to their objective truth." So, we can, concludes Craig, in the end dispense with non-created mathematical objects and there is no embarrassing problem of God and abstract objects.

Discussion about these problems is very much alive and there can be six principal views that are identified..$^{15}$

Though we see that this is interesting philosophico-theological problem, most people are not even aware of this and I doubt that someone's fundaments regarding practical faith would be seriously moved even when heard about this problem. So, it is best that it be left for professionals to try to solve it.

\subsection{Philosophical Theology}

Let me now present an example of more significant problem, both theoretically and practically, which is also an example of the third kind mentioned above. One thing that concerns human beings and human activity is whether we are free beings. It is well-known free will problem or the free will question. This is a question that can be reasoned about using reason only, at least at the first instance, but where certain fundamental issues of faith and theology can already be accounted for. But Catholics (as well as other Christians) are, in fact, faced with two problems of freedom of the will.

There is general problem of freedom of the will concerning what in fact the freedom of will and action mean and whether it obtains in this universe that we inhabit. First, you can be an incompatibilist and argue that concepts »freedom» and »determinism « are not compatible, or you can consider them in a qualified way compatible, so you are a compatibilist. If you are incompatibilist and you think and argue that freedom is possible, then you are libertarian, otherwise you are hard determinist.

We can try to resolve the precise meanings of (fundamental) concepts surrounding this problem and their connections, interrelations and dependencies. The fundamental concepts are, of course freedom, free, determinism, indeterminism, will, deciding, deliberating, action, acting, causing, agency. We try to find possible coherent frameworks what in fact is the freedom of the will - how can it be that, for example, under the same circumstances, both internal and external, until time $t$, one can choose both $\mathrm{A}$ and not- $\mathrm{A}$, i.e. that at least two different possibilities for future action are genuinely open to an agent. Plausible solution that is in accordance, for example, with Catholic teaching to this question would give us a strong libertarian framework. ${ }^{16}$ So, if possible, (I think that

\footnotetext{
${ }^{15}$ See Paul GOULD (ed.), Beyond the Control of God? Six Views on the Problem of God and Abstract Objects, New York, Bloomsbury, 2014.

${ }^{16}$ Good example of early statement of what can be called libertarianism is St. Justin the MARTYR, First Apology, chapter XLIII, trans. Alexander Roberts and James Donaldson, http://
} 
it is, of course), then we would have rational solution to the problem given by reason alone, or almost alone, because we carefully take established facts of the world as granted, and we would have independently provided answer to what is held in Christian faith, that human beings are free and can make self-decisions for themselves. Of course, there can be arguments for libertarianism that explicitly invoke some theistic claim as well.

The second problem of freedom of the will is exclusively theistic, though there is a similar secular variant in the guise of the fatalism problem for free will question. Here is where certain fundamental issues of faith and theology can already be accounted for and are the main content of the debate. Namely, it occurred already to Boethiu ${ }^{17}$ that if God is omniscient, He knows what the future is like and so He knows what created human beings will do in their future. Since you cannot even be in a possibility to render God's knowledge false - then God's knowledge would not, in fact be knowledge, which is impossible, then there is not even a possibility for human beings to do things otherwise than they did them in fact. This flies in the face of Catholic church teaching, because both should be true: God is omniscient (so God has foreknowledge of future contingents) and human beings have freedom of the will and freedom of the action.

This problem is more fundamental and very hard to solve; but there are proposed solutions - dating from Boethius already - he sees God as a temporally eternal so the problem can disappear because then it is improper to say that God knows before you do X that you will do X. There is no before for God if God is not in time. He knows it differently - eternally, which does not bear temporal relations; Ockham ${ }^{18}$ has different solution regarding so called propositions which are »future contingents «, and today debate is very much alive also. ${ }^{19}$

Both kinds of problems about freedom of the will and freedom of the action are more fundamental ones because traditionally human beings, as created by God, are considered as free beings in a very fundamental sense - it is a value by itself, in freedom we are created in image of God, and freedom of the will and freedom of the action is a basis for praise and blame, morally speaking. So,

www.logoslibrary.org/justin/apology1/43.html; for contemporary variants of libertarianism see for example Timothy O'CONNOR, Persons and Causes: the Metaphysics of Free Will, Oxford, Oxford University Press, 2000; Katherine ROGERS, Freedom and Self-Creation: Anselmian Libertarianism, Oxford, Oxford University Press, 2015.

${ }^{17}$ BOETHIUS, The Consolation of Philosophy, trans. Richard Green, Mineola, Dover, 2002, book $\mathrm{V}$.

${ }^{18}$ William OCKHAM, Predestination, God's Foreknowledge, and Future Contingents, trans. Marilyn McCord Adams and Norman Kretzmann, Indianapolis, Hackett Publishing Company, 1983.

${ }^{19}$ See for example John COWBURN, Free Will, Predestination, and Determinism, Milwaukee, Marquette University Press, 2008; John Martin FISCHER and Patrick TODD (eds.), Freedom, Fatalism and Foreknowledge, Oxford, Oxford University Press, 2015; Kevin TIMPE and Daniel SPEAK (eds.), Free Will and Theism, Oxford, Oxford University Press, 2016; Hugh MCCANN (ed.), Free Will and Classical Theism, Oxford, Oxford University Press, 2017. 
according to my opinion, these issues really require philosophical and theological serious considerations, because they may influence and form practical attitudes of faith.

Attempts to solve this problem are a very good example of the third category - of philosophical theology in the first place, but also texts regarding this problem, could fall into any of the three categories mentioned above.

\section{Conclusion}

Let me close with some general thoughts about what I have just said. Though Albert the Great says ${ }^{20}$ that human beings are intellectual beings, capable of understanding and having mind that can very well understand, analyse and combine concepts,-it is not to be expected that people will engage, in larger numbers, in theological and philosophical disputes and discussions, especially not in professional theology and philosophy. These two disciplines are special professions for which you have to have specific knowledge and specific training to engage in its activities in a way that matters professionally and scientifically. But these are not reasons to treat these disciplines as a kind of »surplus«. There is an indirect important impact that these disciplines have even on those large number of people who do not engage directly in these disciplines. Namely, above I said that these disciplines are complementary in settling many doctrinal matters in Catholic faith and matters which matter for everyday life. These things are conferred to people by different means of the Church - doctrinal notes, encyclicals, encyclical letters, through Catholic press, and most important of all, through sermons. These means would not be able to convey essential contents for matters of faith significant for each and every faithful person, if they would not have something to convey in the first place, of course: and that what these means should convey, should be as much as clear and distinct as possible, but not lacking in complexity on the other hand, where complexity is involved. Theology and philosophy many times serve to clarify matters to be prepared to be passed to faithful people, in a clear and appropriate manner.

I would like to end with saying that, regarding western tradition, I consider the exchange and influence in both directions in the relationship between theology and philosophy very much alive, as well as debates and discussions, and I see it as a continuation of a rich history of these two disciplines. I also think that this situation has at least indirect positive influence on a broader community, though we can hardly expect that larger number of people will engage directly in, what we can call, professional debate on philosophical, theological and philosophico-theological matters.

\footnotetext{
${ }^{20}$ Albertus Magnus, De quindecim problematibus, 94-96.
} 


\section{Acknowledgments}

This article is a result in part of the project 5343 supported by Croatian Science Foundation (»Free Will, Causality and Luck«, principal researcher Filip Grgić, 2014-2018) and in part of the project »Existence, Causality and Divine Attributes« supported by the Institute of Philosophy, Zagreb (principal researcher Davor Pećnjak, 2019-). I would like to thank Alojz Cubelić, Tomislav Janović, Stipe Kutleša and the editor of Nova Prisutnost for helpful comments.

\section{Davor Pećnjak* \\ Nekoliko refleksija o Bogu, filozofiji, teologiji i vjeri \\ Sažetak}

U nastojanju da se razumije Bog i vjera na pravi način, filozofija i teologija se mogu izuzetno dopunjavati. Htio bih prikazati i ispitati neke suvremene odnose i izazove između filozofije, teologije i vjere koje se mogu promotriti i iz povijesti ovih disciplina. Razmotrit ću neke točke koje smatram najzanimljivijima. Sugerirat ću da je najvažnija veza između filozofije i teologije trodijelna: postoje čisto filozofska djela koja argumentiraju za teistički zaključak; postoje djela koja filozofski ekspliciraju postojeće teološke sadržaje i postoji filozofska teologija - pomiješane filozofske i teološke komponente gusto isprepletene u tekstu. Dajem primjere zanimljivih problema za obje discipline u ovakvim odnosima te razmatram koje značenje rješenja mogu imati za praktičnu vjeru.

Ključne riječi: Bog, filozofija, katolicizam, teologija, vjera.

\footnotetext{
* Dr. sc. Davor Pećnjak, znanstveni savjetnik, Institut za filozofiju, Ul. Grada Vukovara 54, HR10000 Zagreb, Hrvatska; davor@ifzg.hr.
} 